\title{
Maureen Baker
}

\section{Key Issues in Paid Parental Leave Policy}

In 2002 New Zealand employees gained access to paid parental leave, but other countries established these benefits much earlier and/or used a mix of policy parameters. This article, which is framed within a comparative and feminist political economy perspective, compares paid parental leave programmes in two countries with similar welfare regimes: New Zealand and Canada. The article argues that delivering these benefits through social insurance, as is done in Canada, could elevate benefit levels for some workers but fewer women employees would tend to qualify. Benefits of short duration, as in New Zealand, and those with a low wage-replacement rate tend to discourage employment equity for women. Long-term unpaid parental leave creates similar problems for employment equity outcomes. The article concludes that policy parameters matter, yet the two countries share similar gender equity concerns relating to parental employment and paid leave.

\section{Introduction}

For nearly a century paid parental leave has helped families balance or reconcile earning and caring. This kind of leave has been viewed as a policy which could promote foetal development and children's well-being, workers' rights, and employment equity and job continuity for women (Baker, 2006; Families Commission, 2007; Hantrais, 2004). As early as 1919 the International Labour Organization (ILO) developed a convention articulating women's right to maternity leave, nursing breaks, wage compensation and job protection for its member countries (Heitlinger, 1993, p.90). In 1952 the ILO recommended that governments ensure that workers have access to 12 weeks of paid maternity leave, and this was expanded to 14 weeks in 2000 (ILO, 2000).

In recent decades most developed countries, including New Zealand, have established such benefits, catering to the needs of fathers, partners and adoptive parents as well as birth mothers. This article examines some of the continuing debates about paid parental leave, drawing specifically on policy details from New Zealand and Canada, which are viewed as countries with similar policy backgrounds. However, the paper also 
broadens the cross-national comparisons to several other countries.

New Zealand now provides 14 weeks of paid parental leave benefits at a flat rate, funded through general revenue. In contrast, Canada provides 50 weeks of benefits, financed through social insurance with employer/employee contributions. These different models highlight policy variations within similar countries, yet they share some of the same socio-political concerns about gender equity. It is argued here that the different policy parameters matter in terms of the generosity of paid parental benefits, but outcomes also vary by employees' employment status and sex. Creating more equitable policies for male and female employees in different socioeconomic and employment circumstances remains challenging, given gendered patterns of paid and unpaid work.

\section{New Zealand and Canada: similar welfare regimes?}

Parental benefits in New Zealand and Canada are compared in this article because these countries have been viewed as similar in terms of their policy backgrounds. ${ }^{1}$ Both countries have been categorised as 'liberal' or 'residual' welfare regimes, along with Australia, the United Kingdom and the United States (Baker, 2006; Esping-Andersen, 1990; Lunt, O'Brien and Stephens, 2008; O'Connor, Orloff and Shaver, 1999). These labels refer to the expectation that socio-economic well-being will be derived mainly from earnings and family-based care and that most state support should serve as a social safety net, with social assistance targeted to the poor and needy. In contrast, welfare regimes which depend largely on social insurance programmes funded by employers, employees and the state have been called 'corporatist' or 'conservative' regimes, and largely benefit middleincome earners. Regimes providing universal income support and services have been called 'social democratic', and were designed to promote both income and gender equity (Esping-Andersen, 1990). Numerous researchers have shown that the social democratic regimes typically provide the most generous social programmes, including paid parental leave and public child care (Baker, 2006; Daly and Rake, 2003; Hantrais, 2004; OECD, 2007).

Researchers have disputed the accuracy and validity of classifying welfare regimes these ways, and argue, for example, that New Zealand and Australia differ from the other liberal countries because trade unions historically co-operated with governments in the regulation of wages, production, immigration, imports and exports, rather than encouraging extensive social assistance or insurance programmes (Mitchell, 1995; Castles and
2008; Lunt, O'Brien and Stephens, 2008). Despite these complications, this article views the welfare regimes in Canada and New Zealand as sufficiently similar and classifies them as 'liberal'. However, paid parental leave policies differ in these countries.

\section{The development of paid parental leave}

Before paid parental leave was developed, both countries offered unpaid maternity leave, which included job protection for female employees during the latter stages of pregnancy, pregnancy-related sickness, childbirth and recovery, and

\section{... parental benefits were introduced as a separate social programme which was available to women and men employees (gender-neutral or at least transferable from mothers to fathers).}

Pierson, 1995; Castles and Shirley, 1996). In the historical development of social provision, Australia and New Zealand have been labelled 'wage-earners' welfare states' because high (male) wages were ensured through centralised bargaining and arbitration and limited immigration. In recent decades, however, because of neo-liberal restructuring, New Zealand has come to look more like North America in its social provision (Lunt, O'Brien and Stephens, 2008).

Viewing Canada as a liberal welfare regime is also problematic. While provincial 'welfare' programmes are funded and delivered as targeted social assistance, several federal programmes are financed through contributory social insurance schemes (including maternity and parental benefits) and a few programmes (such as the old age pension) are universal or have been in the past (Baker, 2011; Lightman, 2003). In contrast, New Zealand delivers most social provision through social assistance, except for injury compensation which is a partial social insurance programme and the old age pension, which remains universal (Cheyne, O’Brien and Belgrave, later adoption. Canada first introduced unpaid maternity leave in 1921 in the province of British Columbia (Morris, 2000), while New Zealand introduced it in 1980 (Families Commission, 2007, p.18). Furthermore, maternal employment rates increased in Canada decades before they did in New Zealand, and remain at higher levels (Baker, 2009). For example, $58.7 \%$ of mothers with children under two years of age were employed in Canada in 2005 compared to $45.1 \%$ in New Zealand (OECD, 2007, Table 3.2). In both countries, paid parental leave was introduced much later than unpaid leave.

In New Zealand paid parental leave was made available in 2002, despite much earlier initiatives in other countries (Families Commission, 2007). The New Zealand legislation originated as a private member's bill from a female member of Parliament (Laila Harré) of the left-leaning Alliance Party but was implemented by the Labour-led (Clark) government with a female prime minister (Baker, 2008). After considerable discussion, parental benefits were introduced as a separate social programme which was available to women and men employees (gender- 
neutral or at least transferable from mothers to fathers). Initially, 12 weeks of paid job-protected leave was provided for new parents who had worked for the same employer for a year, but this was later extended (ibid.).

In Canada paid maternity leave was introduced as social insurance in 1971, at a time when maternal employment rates were rapidly increasing. Initially, gender-specific maternity benefits were developed by the (Trudeau) Liberal government (then centre-left) and offered or from social insurance contributions (as in Canada). If parental benefits are financed from general revenue, the benefit level often approximates that of other 'welfare' payments, although benefits can be paid at a slightly higher rate (as is the case in Australia and New Zealand). If they are financed through social insurance and vary with employment earnings, payments are more generous for employees with higher pre-leave earnings (more often fathers and full-time workers), but fewer new

\section{In a 2007 report the New Zealand Families Commission argued that the duration of leave was too short and recommended that paid parental leave be expanded in three phases until it reached a maximum of 56 weeks by 2015 .}

to eligible female employees for 15 weeks as part of the existing Unemployment Insurance Program (later renamed Employment Insurance). In 1990 genderneutral parental benefits were added, prompted by a challenge on the basis of the Canadian Charter of Rights and Freedoms by a man who successfully argued that biological fathers should have access to the same benefits as adoptive parents. Parental benefits were extended again in 2001, while the maternity benefits were retained (Marshall, 2008).

\section{Funding paid parental leave}

In New Zealand paid parental leave is funded from general revenue and paid at a flat rate. In Canada it is funded by contributions from employees and employers, and paid as a percentage of previous earnings and payroll. Canadian benefits are based on employees' work record and wage-related contributions to unemployment insurance, regardless of their household income.

The financing of maternity/ parental benefits remains controversial internationally. These programmes are usually financed either through general revenue (as in New Zealand and Australia) parents will qualify. Both employers and employees could be required to pay social insurance premiums. Alternatively, only one of these might pay, with government also contributing, as used to be the case in Canada.

The replacement rate of previous wages varies from $100 \%$ in several European countries (such as France, Germany and Norway) to $55 \%$ of previous earnings in Canada, to nothing in most of the United States (Baker, 2006). Where replacement rates are low and other social benefits for caring are unavailable, mothers often take less than the maximum leave entitlement because the household needs their full earnings for economic survival.

Adding parental benefits to social insurance programmes changes the original understandings behind them. When they form part of unemployment insurance, the age-old expectation that the unemployed worker is available for work is altered. Furthermore, because payments are based on previous work record and earnings, fewer women than men qualify and women receive lower average payments than men (MacDonald, 2009). Where they form part of disability or sickness benefits, childbirth and adoption are falsely portrayed as illnesses or disabilities. However, providing gender-neutral leave programmes that could be used by either males or females has sometimes dampened employer opposition, especially to contributory social insurance schemes.

Eligibility and duration of paid parental leave Fourteen weeks of paid parental leave are now available in New Zealand to eligible female employees giving birth to a child, to her employed spouse or partner if the birth mother chooses to transfer this leave, or to new parents caring for an adoptive child under 6 years of age (Department of Labour, 2011). Eligible employees must have worked for at least 10 hours a week for the same employer for 6-12 months depending on category of leave, or as a self-employed person, and could receive a maximum flat-rate payment (ibid.). Most mothers find that this period of paid leave is too short and either take additional unpaid leave (up to one year is permitted) or quit their jobs (Department of Labour, 2007). If they quit their jobs before the end of the 14 weeks, their payments cease.

In a 2007 report the New Zealand Families Commission argued that the duration of leave was too short and recommended that paid parental leave be expanded in three phases until it reached a maximum of 56 weeks by 2015 . This would include 14 weeks' maternity leave, 4 weeks' paternity/partner leave and 38 weeks of family leave (Families Commission, 2007, p.9). Crichton (2008) found that the majority of birth mothers do not return to work immediately after their 14 weeks of paid leave, and only three-quarters return after one year. New mothers who return to work often reduce their paid working hours, change to less stressful but lower-paid jobs, or quit their jobs altogether. Baker (2010) found that mothers are more likely to follow this pattern in New Zealand than in Canada, especially after the second or third child. Canadian parental benefits are available for a much longer duration: 15 weeks for women's maternity benefits and 35 weeks for parental benefits, totalling 50 weeks altogether.

The ideal duration of parental benefits remains contentious internationally. 
Many OECD countries offer a relatively short period of parental benefits (about 14 weeks), with the option of longer unpaid leave or extended leave at a lower rate. However, Sweden provides 480 days to either parent (but not both at once). A short leave period which forces employees to return to work quickly after childbirth could encourage maternal or infant health problems, discourage breastfeeding, and lead to difficulties finding and paying for infant child care (UNICEF, 2008).

\section{Comparing the value of parental benefits}

If we compare the maximum value of paid parental benefits in New Zealand and Canada, we find that they are worth slightly more than half of the national median wage in each country, although wages are somewhat higher in Canada (Statistics Canada, 2010). However, we need to acknowledge that many Canadian workers do not receive the maximum payment, yet the duration of benefits is much longer than in New Zealand.

The maximum value of paid parental leave in New Zealand is \$NZ458.82 before tax (Department of Labour, 2011), which is considerably higher than the unemployment benefit or the basic domestic purposes benefit for sole parents caring for children at home (WINZ, 2010). ${ }^{2}$ The maximum value of paid parental benefits represents about $55 \%$ of the median wage of employed people (Statistics New Zealand, 2010). The 2007 Families Commission report recommended that this be raised to $100 \%$ of average weekly full-time earnings for 14 weeks of maternity and 4 weeks of paternity/partner leave and 66\% for family leave (Families Commission, 2007, p.10).

In Canada, parental benefits have a maximum value in Canadian dollars of $\$ 468$ per week and replace up to $55 \%$ of average insured earnings to a yearly maximum of $\$ 44,200$ (Service Canada, 2011). ${ }^{3}$ However, more women than men work part-time or in contractually limited jobs, and in this type of social insurance the value of benefits is directly related to the hours an employee worked in the previous year and to their earnings (to a ceiling).
To qualify for employment insurance (and therefore for maternity/parental benefits), Canadian workers must have accrued from 420 to 700 hours of 'insurable work' in the previous 52 weeks, with eligibility varying by the applicant's place of residence and unemployment rates in their region (Service Canada, much higher rate, the national minimum wage of $\$ \mathrm{~A} 570$ per week before tax (Australian Government, 2011). ${ }^{4}$ This will undoubtedly encourage advocacy groups such as the Child Poverty Action Group to pressure the government for improved paid parental leave in New Zealand (One News, 2011).

\section{Leaving employment for child bearing and returning years later was feasible for women when labour markets were expanding in the 1960 s, enabling them to re-enter more easily.}

2010). This means that women in low unemployment areas would have to work at least 13 hours per week in the previous year in order to qualify for paid parental leave. However, eligible mothers could combine maternity and parental benefits and receive them for 50 weeks (compared to 14 weeks in New Zealand), while men could receive a maximum of 35 weeks in Canada.

Researchers have attempted to compare the value of parental leave for different countries but this is complicated because leave may be long with low payments or short with high payments. UNICEF produced a table based on 2008 data comparing 'effective parental leave', which is calculated as the duration of statutory leave multiplied by salary paid. Table 1 includes selected countries from this table, showing that Canada's paid parental leave is more generous than New Zealand's, largely because of the duration.

Both countries pay considerably less than all the social democratic countries (especially Norway) and some corporatist countries, such as France (UNICEF, 2008, p.16). The United States continues to offer no statutory benefits at the federal level, but Australia introduced paid parental leave in January 2011 (postdating the data in Table 1). The Australian benefit is government-funded, like New Zealand's, but is paid for 18 weeks at a
Table 1: Effective parental leave (duration of statutory leave multiplied by salary paid), 2008

\begin{tabular}{lr}
\hline Country & $\begin{array}{r}\text { Effective } \\
\text { parental leave }\end{array}$ \\
\hline Australia and United & 0 \\
\hline States & 7 \\
\hline New Zealand & 29 \\
\hline Sweden & 48 \\
\hline Denmark & 53 \\
\hline Finland & 57 \\
\hline France & 103 \\
\hline Norway & 116 \\
\hline
\end{tabular}

Source: UNICEF, 2008, p.16

Interest groups and maternity/parental leave Over the past century the development of maternity/parental leave legislation throughout the Western world has served varying interests. The early genderspecific maternity leave policies were based on the reality that only women get pregnant, give birth and lactate, as well as a concern for maternal and child health and welfare. Allowing pregnant women to take job-protected leave recognises potential health risks to foetuses and mothers from overwork or exposure to work-related hazards. Permitting recovery 
time acknowledges that childbirth is physically and psychologically exhausting. Consequently, health and safety advocates, religious groups, and conservative women's groups have argued for genderspecific maternity leave (Baker, 2006; Heitlinger, 1993).

Maternity leave legislation has also been used to increase women's employment rates. If, after working for a designated period, women are guaranteed paid leave while their positions are held open, they are more likely to enter paid households can survive on one income and many parents are working longer hours (Families Commission, 2009; OECD, 2007). Furthermore, fewer homemakers can depend on another household wage in an era of high separation and divorce rates. Although women have always paid a heavy price in lifetime earnings for moving in and out of paid work, maternity leave provisions have improved their economic status considerably (OECD, 2007). Consequently, women's groups, 'progressive' reform groups

\section{Gender-neutral parental leave legislation has been motivated by efforts to increase the opportunities and rights of fathers to care for their infants and young children with minimal income loss.}

work and to ensure that they have met eligibility qualifications before becoming pregnant (Duvander et al., 2010; Families Commission, 2007). Leaving employment for child bearing and returning years later was feasible for women when labour markets were expanding in the 1960s, enabling them to re-enter more easily. It was also easier when technological change was slower, men were paid a family wage and separation/divorce rates were lower.

Under current conditions reentering the workforce has become more challenging, with shrinking labour markets, increased global competition and rapid technological change. Considerable research now discusses the impact of the 'child penalty' or 'motherhood penalty' on the employment patterns and lifetime earnings of women, comparing mothers with childless women. This research notes that the number of children and time outside the labour force are critical variables reducing maternal earnings, especially for educated mothers (Baker, 2010; Correll et al., 2007; Families Commission, 2007; OECD, 2007; Zhang 2009).

As living costs and consumption increase, a smaller percentage of and trade unions have fought for paid maternity leave, although there has been more debate about the wisdom of longterm leave for promoting gender equity in the home and workforce.

Gender-neutral parental leave legislation has been motivated by efforts to increase the opportunities and rights of fathers to care for their infants and young children with minimal income loss. For example, the creation of parental benefits in Canada resulted from a constitutional challenge focusing on the differential entitlements between adoptive parents and biological fathers, rather than from any substantial change in men's caring roles (Baker, 2006, p.132). Traditionally, men have been encouraged to give priority to earning rather than caring, but parental leave legislation acknowledges that some men want to play a larger role in their children's care and development. However, only a minority of fathers takes their full entitlement of paid parental leave even when their wages are fully reimbursed. Men who take parental leave spend more time caring for their children but they may be a self-selected group with more interest in nurturing (Marshall, 2008). Consequently, some countries, such as Norway, have legislated that fathers must take several weeks of parental leave or the couple will forfeit this portion, which has slightly raised men's take-up rate (Duvander et al., 2010; Families Commission, 2007, p.40).

Despite the different interests and origins of parental and maternity leave, caring work continues to be gendered. In all OECD countries women tend to shoulder the responsibility for child care, housework and 'kin-keeping', and they more often work part-time, even in the social democratic countries (Baker, 2006; Leira, 2002; OECD, 2007; OECD, 2009). Feminists and progressive reformers argue that paid maternity/ parental leave is essential for gender equity, as it can encourage young women to delay childbirth and establish fulltime employment before pregnancy. In comparative analyses, paid maternity/ parental leave and adequate childcare are two important factors in determining the lifetime earnings of women (Christopher, 2002; OECD, 2008). Paid parental leave can also contribute to poverty reduction, especially in sole-mother households, as there is no need to resign from employment in order to have and raise children.

\section{Male biases in parental leave programmes}

In the OECD countries wide variation is apparent in the motivating philosophy, the duration of benefits and the compensation levels of maternity/parental leave (OECD, 2007). Yet the underlying structure of legislation often assumes that male work characteristics are the norm. Entitlement (even for unpaid parental leave) is sometimes based on a lengthy work record in standard employment for the same employer, even though many women work in temporary or part-time positions (Baker, 2006; Whitehouse, 2005).

Policy makers have attempted to remove biases from parental leave legislation in recent decades. For example, France, Germany and Sweden now offer government benefits to pregnant women regardless of their workforce attachment (Baker, 2006). New Zealand and several Canadian provinces have reduced or eliminated the requirements of a lengthy employment record because 
they disqualified many women from leave and benefits. In 1996 Canada began to base eligibility on the number of hours employees previously worked rather than weeks, allegedly to help more 'non-standard' workers become eligible, although benefit levels were reduced in the process (Baker and Tippin, 1999, p.97). The Canadian government also extended benefit duration from 10 to 35 weeks in 2001, bringing the duration of maternity/parental benefits up to 50 weeks (Marshall, 2008). In New Zealand, the duration of parental benefits was extended in 2005 from 12 to 14 weeks, after pressure from local interest groups but also from the ILO, and the continuous employment requirement was reduced. Now, additional pressure to reform paid parental leave in New Zealand will likely arise from the new Australian scheme.

The gendered nature of paid work and different use of parental leave by men and women contribute to the unequal sharing of economic and practical parenting, making it difficult to create social policies without gendered outcomes. When parenting is divided, fathers usually assume economic parenting, acquiring full-time or overtime paid work (Baker, 2009; Callister, 2005). In contrast, mothers often perpetuate their economic dependency through practical parenting (performing routine household tasks and child care), because they want to and because it is still viewed as 'women's work', but also because they are less able than fathers to find high-paying and permanent full-time jobs. If only one parent at a time is permitted to take parental leave, which is usually the case, the family is better able to survive on the father's (usually) higher wage (Families Commission, 2007; OECD, 2007). Both men and women view mothers as the logical choice for parental leave as mothers already take time off work for childbirth and recovery; therefore, the decision to take all or most of the leave could easily follow.

Fathers seldom take extended parental leave even when it is paid, but mothers with another household earner sometimes use extended unpaid leave instead of purchasing infant child care. However, taking unpaid leave is only possible for households with adequate resources and could perpetuate a gendered division of labour at home. In other words, both the duration and level of parental benefits could influence parental behaviour, the household division of labour and women's employment patterns.

Women's employment rates are clearly influenced by access to paid parental leave and affordable child-care services, but are also influenced by high divorce rates, low wages or unemployment of male partners, ideologies elevating paid work insistence on treating men and women equally in terms of employment leave benefits is ironic considering that women give birth and lactate while men do not. However, the US Constitution requires equal treatment for men and women (Baker, 2006).

A second trend is the extension of unpaid parental leave to periods of from one to five years. Offering extended leave can help resolve the high cost and shortage of infant child care without expanding public funding. In addition,

\section{Women's employment rates are clearly influenced by access to paid parental leave and affordable child- care services, but are also influenced by high divorce rates, low wages or unemployment of male partners, ... lack of state support to raise children at home, and personal/cultural preferences.}

and economic self-sufficiency, women's educational qualifications, lack of state support to raise children at home, and personal/cultural preferences. Policies that pay mothers to stay home and care for their children for extended periods of time (more than several years) serve to reinforce traditional gender relations. After several years at home a woman's role as care provider and homemaker tends to become solidified and her job skills, employment experience and earning capacity are subsequently eroded (OECD, 2007; Ranson, 2009).

\section{International trends in parental leave}

Two international trends have been apparent in parental leave policies. First, gender-neutral terminology is increasingly used to equalise benefits for males and females (as well as biological and adoptive parents), and paid parental leave has replaced maternity leave in some jurisdictions and workplaces. In the United States, for example, maternity benefits have been perceived as discriminatory to fathers unless they are incorporated into sickness and disability insurance. This extended leave allows mothers who choose to care for their own children and who can afford to forfeit their earnings to do so without relinquishing their jobs. Extended parental leave also reduces absenteeism, by temporarily replacing parents of infants or young children with employees who have fewer domestic responsibilities. And finally, it can help reduce unemployment by offering shortterm contracts as maternity replacements, providing invaluable job experience for otherwise unemployed or marginally employed people. Yet extended unpaid leave is only an option for higher-income and two-parent families, and could work against women's equality by solidifying traditional gender roles (Daly and Rake, 2003; Families Commission, 2007; Heitlinger, 1993).

\section{Conclusions}

In the distant past New Zealand was viewed as a policy innovator for some forms of social provision, but this has not been the case for paid parental leave, which was introduced decades later than in Canada and with a much shorter duration. 
Initiating or reforming social programmes clearly requires effective lobbying and coalition building. Advocates for improvements to parental benefits (such as the Families Commission and the Child Poverty Action Group) are now arguing that statutory supports and services for parents who are balancing employment and family life are essential for poverty reduction, women's employment equity and children's well-being. However, expanding social programmes requires political commitment and the investment of public money, which is especially difficult in an era of neo-liberalism, with competing demands for smaller government and lower income taxes.

Social conservatives continue to resist expanding any form of income support unless other benefits are simultaneously cut. An underlying concern in many countries is that encouraging more women into employment could increase unemployment rates, reduce fertility rates, leave children with insufficient supervision, and diminish respect for the male breadwinner family. Clearly, the state must be seen as fair and equitable when providing social benefits and tax relief, ensuring that women and households are not penalised economically when they reproduce. Nevertheless, the persistence of gendered employment patterns raises questions about the adequacy of the welfare state in securing women's welfare (Daly and Rake, 2003).

Clearly, paid parental leave is essential for women's employment equity. Combined with subsidised child care services, these programmes can help to resolve the gender-based inequalities in the workplace and home. However, the design of maternity/parental leave programmes must acknowledge that employment choices and constraints have never been the same for most mothers and fathers. Family obligations continue to encourage more mothers to accept part-time or temporary employment, to limit overtime, take unpaid leave, relocate with their partner's occupational moves, and accept low-wage jobs. Social programme development must acknowledge gendered patterns of work but also strive to promote gender equity in the workplace.

\footnotetext{
1 With the exception of Quebec.

2 As of April 2011 the value of the unemployment benefit and the DPB for a mother caring for a child is worth $\$ 326.82$.

3 The Canadian dollar equalled 1.26 cents New Zealand on 2 June 2011 . The average weekly wage is about $\$ 884$ Canadian per week (Statistics Canada, 2010).

4 The Australian dollar was worth \$NZ1.31 as of 2 June 2011.
}

\section{References}

Australian Government, Family Assistance Office (2011) 'Paid parental leave scheme for working parents', http://www.familyassist.gov.au/ payments/family-assistance-payments/paid-parental-leave-scheme/

Baker, M. (2006) Restructuring Family Policies: convergences and divergences, Toronto: University of Toronto Press

Baker, M. (2008) 'Low-income mothers, employment and welfare restructuring', in N. Lunt, M. O'Brien and R. Stephens (eds), New Zealand, New Welfare, Auckland: CENGAGE Learning

Baker, M. (2009) 'Working their way out of poverty? Gendered employment in three welfare states', Journal of Comparative Family Studies, 40 (4), pp.617-34

Baker, M. (2010) 'Motherhood, employment and the "child penalty"', Women's Studies International Forum, 33, pp.215-24

Baker, M. (2011) 'Revisiting the 'dual welfare state': sickness, injury and unemployment programs in two 'liberal' regimes', Women's Health and Urban Life, special edition, 10 (1), pp.10-31

Baker, M. and D. Tippin (1999) Poverty, Social Assistance and the Employability of Mothers: restructuring welfare states, Toronto: University of Toronto Press

Callister, P. (2005) 'The changing gender distribution of paid and unpaid work in New Zealand', working paper 05/07, Wellington: Treasury

Castles, F. \& C.pierson (1995). 'New Convergence? Recent Policy Developments in the United Kingdom, Australia and New Zealand', Policy and Politics 24 (3): 233-45.

Castle, F. \& I. Shirley (1996). 'Labour and Social Policy: Gravediggers or Refurbishers of the Welfare State?' In The Great Experiment: Labour Parties and Public Policy Transformation in Australia, and New Zealand, 88-106. Edited by F. Castles, R. Gerritsen and J. Vowles. AucklandL Auckland University Press.

Cheyne, C., M. O'Brien and M. Belgrave (2008) Social Policy in Aotearoa New Zealand: a critical introduction (4th edn), Melbourne: Oxford University Press

Christopher, K. (2002) 'Welfare state regimes and mothers' poverty', Social Politics, 9 (1), spring, pp.60-86
Correll, S., S. Benard and I. Paik (2007) 'Getting a job: Is there a motherhood penalty?', American Journal of Sociology, 112 (5), pp.1297-338

Crichton, S. (2008) Work Patterns after Paid Parental Leave, Wellington: Department of Labour and Statistics New Zealand

Daly, M. and K. Rake (2003) Gender and the Welfare State, Cambridge: Polity Press

Department of Labour (2007) Parental Leave in New Zealand: 2005/6 evaluation, www.dol.govt.nz

Department of Labour (2011) Parental Leave, www.dol.govt.nz

Duvander, A., T. Lappegard and G. Andersson (2010) 'Family policy and fertility: fathers' and mothers' use of parental leave and continued childbearing in Norway and Sweden', Journal of European Social Policy, 20 (1), pp.45-57

Esping-Anderson, G. The Three Worlds of Welfare Capitalism. Cambridge: Polity Press, 1990.

Families Commission (2007) It's About Time: towards a parental leave policy that gives New Zealand families real choice, research report 3/07, Wellington: Families Commission

Families Commission (2009) Finding Time: parents' long working hours and the impact on family life, research report 2/09, Wellington: Families Commission

Hantrais, L. (2000) Social Policy in the European Union, 2nd edn, UK: Macmillan

Hantrais, L. (2004) Family Policy Matters: responding to family change in Europe, Bristol: The Policy Press

Heitlinger, A. (1993) Women's Equality, Demography, and Public Policy: a comparative perspective, London: Macmillan

International Labour Organization (ILO) (2000) International labour standards on maternity protection, www.ilo.org

Leira, A. (2002) Working Parents and the Welfare State: family change and policy reform in Scandinavia, Cambridge: Cambridge University Press

Lightman, E (2003) Social Policy in Canada, Toronto: Oxford University Press 
Lunt, N., M. O'Brien and R. Stephens (eds) (2008) New Zealand, New Welfare, Auckland: CENGAGE Learning

Marshall, K. (2008). 'Fathers' use of paid parental leave', Perspectives, June, pp.5-14

MacDonald, M. (2009) 'Income security for women: what about employment insurance?', in M Cohen and J. Pulkingham (eds), Public Policy for Women, Toronto: University of Toronto Press

Mitchell, D. (1995). 'Women's Incomes, In Women in Restructuring Australia: Work and Welfare, 79-94. Edited by A. Edwards and S. Magarey. Sydney: Allen and Unwin.

Morris, M. (2000) 'Some facts and dates in Canadian women's history of the 20th century', Canadian Research Institute for the Advancement of Women Newsletter, 20 (1)

OECD (2007) Babies and Bosses: reconciling work and family life (vol 5), Paris: OECD

OECD (2008) Growing Unequal? Income distribution and poverty in OECD countries, Paris: OECD

OECD (2009) Society at a Glance 2009. OECD social indicators, Paris: OECD

One News (2011) 'Calls to improve NZ's paid parental leave system', 18 January, Television New Zealand One News
Ranson, G. (2009) 'Paid and unpaid work: how do families divide their labour?', in M. Baker (ed.), Families: changing trends in Canada (6th edn), Toronto: McGraw-Hill Ryerson

Service Canada (2010) Unemployment insurance regular benefits, www. servicecanada.gc.ca

Service Canada (2011) Employment insurance and maternity, parental and sickness benefits, www.servicecanada.gc.ca

Statistics Canada (2010) Wages, salaries and other earnings, www40. statcan.ca

Statistics New Zealand (2010) NZ Income Survey, June 2010, Wellington: Statistics New Zealand, www.stats.govt.nz

UNICEF (2008) The Child Care Transition, Innocenti report card 8, Florence: UNICEF

United Nations (2000) The World's Women: trends and statistics, New York: United Nations

Whitehouse, G. (2005) 'Access to parental leave in Australia: evidence from negotiating the life course', Australian Journal of Social Issues, 40 (4), pp.489-503

WINZ (Work and Income New Zealand) (2010) (www.workandincome. govt.nz)

Zhang, X. (2009) 'Earnings of women with and without children', Perspectives, March, pp.5-13

\section{Resilience in the Pacific Addressing the Critical Issues}

\section{Edited by Brian Lynch and Graham Hassall}

In February 2011 the New Zealand Institute of International Affairs and the Institute of Policy Studies, Victoria University of Wellington, co-hosted a conference that sought to bring fresh insights into the formidable array of challenges facing New Zealand's Pacific neighbours. The focus of the conference was on the nature, relevance and implications of the concept of 'resilience' as applied in the Pacific, in the face of those daunting challenges. Most of the texts presented at the conference are included in this book. It will be seen that collectively they highlight the seeming intractability of long-standing regional and local problems as well as the new range of issues confronted by our nearneighbours including climate change, cross-border crime, labour mobility, and the intrusion of great-power rivalries into the region.

Yet grounds for cautious optimism were also identified. Speakers pointed to areas of opportunity under-valued or untapped: in developing visionary leadership, building self-confidence, utilising the strengths and loyalties of the Pacific 'diaspora', adopting more ambitious schemes of infra structure development, promoting better awareness of the quality of Pacific products, and focussing donor perceptions more on the potential of the formal aid programme to function as an enabler to progress not as growth constraint.

The dialogue on ways of tackling Pacific issues more effectively is destined to continue for a long time and this book is an important contribution to that ongoing conversation.

\section{Resilience in the Pacific Addressing the Critical Issues}

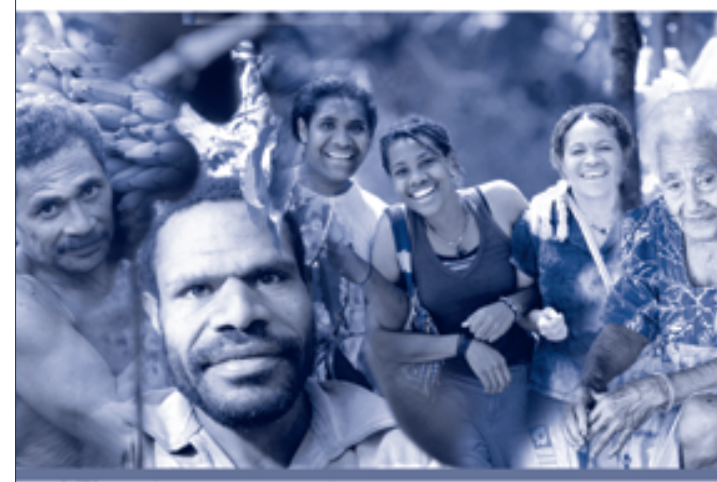

Edited by Brian Lynch and Graham Hassall

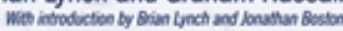

An Institute of Policy Studies and New Zealand Institute of International Affairs publication

Edited by Brian Lynch and Graham Hassall

Publication Date: April 2011. Format A5 Paperback, pp 201

ISBN 978-0-908772-36-0 Price - \$27.60 (including P\&P within New Zealand)

Place your order by email, phone, fax or mail to

Institute of Policy Studies, Victoria University of Wellington

Email ips@vuw.ac.nz Telephone +64 44635307

P0 Box 600, Wellington, New Zealand

An invoice will be issued with your order

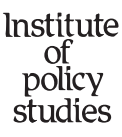

